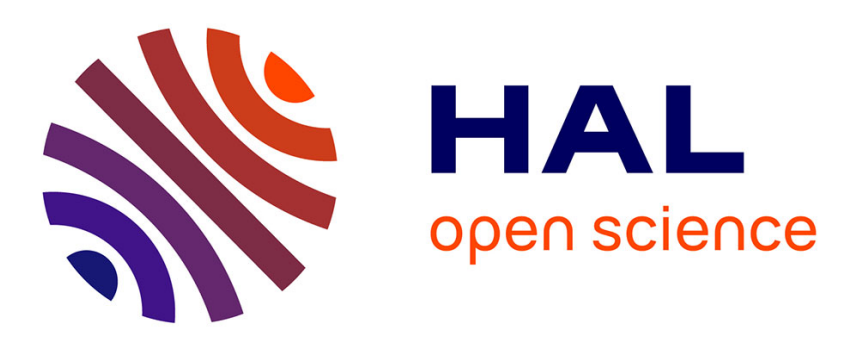

\title{
Laboratory artificial infection of hard ticks: a tool for the analysis of tick-borne pathogen transmission
}

\author{
Sarah Bonnet, Xiangye Liu
}

\section{To cite this version:}

Sarah Bonnet, Xiangye Liu. Laboratory artificial infection of hard ticks: a tool for the analysis of tickborne pathogen transmission. Acarologia, 2012, 52 (4), pp.453-464. 10.1051/acarologia/20122068 . hal-01301271

\section{HAL Id: hal-01301271 \\ https://hal.science/hal-01301271}

Submitted on 11 Apr 2016

HAL is a multi-disciplinary open access archive for the deposit and dissemination of scientific research documents, whether they are published or not. The documents may come from teaching and research institutions in France or abroad, or from public or private research centers.
L'archive ouverte pluridisciplinaire HAL, est destinée au dépôt et à la diffusion de documents scientifiques de niveau recherche, publiés ou non, émanant des établissements d'enseignement et de recherche français ou étrangers, des laboratoires publics ou privés. 


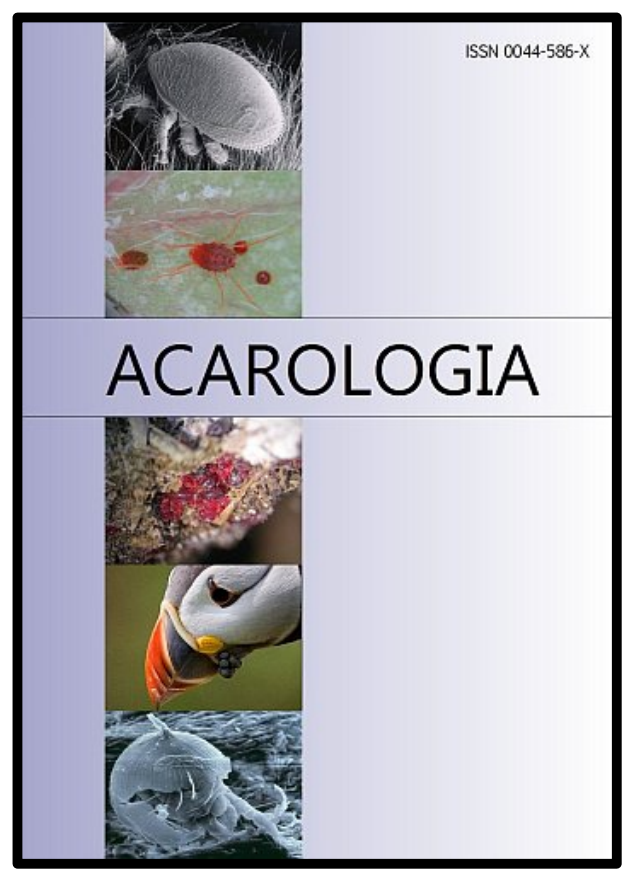

\section{ACAROLOGIA}

A quarterly journal of acarology, since 1959

Publishing on all aspects of the Acari

All information:

http://www1.montpellier.inra.fr/CBGP/acarologia/ acarologia@supagro.inra.fr

\section{OPEN ACCESS}

\section{Acarologia is proudly non-profit, with no page charges and free open access}

Please help us maintain this system by encouraging your institutes to subscribe to the print version of the journal and by sending us your high quality research on the Acari.

Subscriptions: Year 2016 (Volume 56): $300 €$ http://www1.montpellier.inra.fr/CBGP/acarologia/subscribe.php

Previous volumes (2010-2015): $220 €$ / year (4 issues) Acarologia, CBGP, CS 30016, 34988 MONTFERRIER-sur-LEZ Cedex, France

Acarologia is under free license and distributed under the terms of the

Creative Commons-BY-NC-ND which permits unrestricted non-commercial use, distribution, and reproduction in any medium, provided the original author and source are credited. 


\title{
LABORATORY ARTIFICIAL INFECTION OF HARD TICKS: A TOOL FOR THE ANALYSIS OF TICK-BORNE PATHOGEN TRANSMISSION
}

\author{
Sarah BONNET and Xiang Ye LiU
}

(Received 12 March 2012; accepted 13 August 2012; published online 21 December 2012)

USC INRA Bartonella-tiques, UMR BIPAR ENVA-ANSES-UPEC, 23 Avenue du Général de Gaulle, 94706 Maisons-Alfort cedex, France. sbonnet@vet-alfort.fr, xliu@vet-alfort.fr

\begin{abstract}
Despite its importance, our knowledge of pathogen transmission by ticks is incomplete. Detailed studies on the transmission, maintenance, infectivity, virulence, and pathogenicity of tick-borne microparasites all require the use of large numbers of live ticks raised under controlled conditions and difficulties in rearing ticks in the laboratory could partly explain the current lack of data. The most complex part in maintaining tick colonies doubtlessly lies in their engorgement, as ticks are strict haematophagous arthropods. Indeed, relatively few research teams have worked on artificial feeding systems for ticks due to the long, complex, and poorly understood feeding patterns of these arthropods. It is nonetheless essential to investigate the mechanisms underlying tick infection and infectiousness in order to better understand parasite-host-vector relationships and elaborate new control strategies for transmitted pathogens. The various methods used to date to feed ticks and infect them with their associated pathogens are reviewed here and their advantages and inconveniences are discussed.
\end{abstract}

KEYWORDS - ticks; artificial feeding; in vitro infection

\section{INTRODUCTION}

Ticks are among the most important vectors of human and animal diseases and surpass all other arthropods in the variety of pathogenic organisms they can transmit: including fungi, viruses, bacteria and protozoa. To study the biology of ticks or their interactions with associated pathogens, it is indispensable to be able to maintain tick colonies under laboratory conditions and to have efficient techniques to artificially infect them. In addition, it is widely recognized that the dynamics, pathogenesis and symptoms of infection, as well as the subsequent immune response, strongly depend on the route of pathogen introduction into a suscepti- ble vertebrate host (Crippa et al. 2002; de Souza et al. 1993; Gern et al. 1993; Massung et al. 2004; Motameni et al. 2005; Piesman 1993). During natural transmission, tick-borne pathogens are injected into the vertebrate host at the same time as tick saliva, which favors infection by interfering with host immunological responses (Nuttall 1999). This means that studying tick-borne pathogen transmission to vertebrate hosts requires that ticks be infected under laboratory conditions.

However, rearing ticks, and in particular hard ticks, is not easy due to their complex biological cycle. The problems encountered in the maintenance of productive laboratory colonies doubtlessly explain a significant proportion of the existing 
gaps in our knowledge of tick vector competence and transmission pathways. The Ixodidae likely possess the most complex feeding biology of all hematophagous arthropods. Indeed, the fact that they only feed on blood, and do so for an extended period of time (3-12 days), greatly limits our ability to set up artificial feeding systems which can function over the required time intervals. Several methods have been developed and used to infect hard ticks with pathogens, including feeding ticks on infected animals, injecting pathogens through the cuticle, using capillary tubes filled with infectious suspensions to feed ticks, and feeding them on artificial or animal-derived membranes. In this review, we summarize each of these techniques, discuss their application to pathogen transmission, and present their strengths and weaknesses (summarized in the Table 1). However, we first start with a brief outline of the Ixodid tick life cycle and highlight the importance of considering tick biology and ecology when attempting artificial feeding and tick rearing in the laboratory.

\section{Overview of the hard tick life cycle}

The general life cycle for hard tick species can be found in Sonenshine (1991). Here, we summarise the main points that are important to consider for artificial tick infections. Hard ticks have larval, nymphal and adult forms, all of which require a blood meal. Adult ticks tend to be restricted to feed on large-bodied animal hosts, whereas larval and nymphal stages also exploit smaller animals. For many species, Humans can be incidental hosts to the three life stages. A three-host life cycle, which includes host-seeking, feeding and off-host moulting (or egg-laying) in each life stage, is the most common developmental pattern for the majority of hard ticks of medical and veterinary interest. After feeding on a rather substantial quantity of host blood, females drop from the hosts and commence oviposition in a sheltered microenvironment, laying up to several thousand eggs. During each life stage, ticks may enter diapause for a variable amount of time depending on environmental conditions. Under favorable conditions in the natural environment, the life cycle of three-host tick species, from larval hatching to the hatching of the next larval generation, can be completed in less than one year, but is typically longer (2-3 years). Compared with other haematophagous arthropods, feeding ixodid ticks is therefore a slow and complex process, taking several days to several weeks for repletion and detachment alone. In addition, successful host attachment depends on the presence of an appropriate array of chemical and physical stimuli that entice ticks into feeding.

\section{Laboratory-adapted conditions for tick feeding}

Most species of non-nidicolous ticks (or exophilic ticks, i.e. that occupy open, exposed habitats) have a clear, well-defined seasonal period of activity, during which time they engage in questing, a behavior expressed by the willingness of the tick to crawl or climb to favorable locations where they may attach to passing hosts. This active period can vary within the zoogeographic range of the species and among life stages (Sonenshine, 1991). Under laboratory conditions, photoperiod and ambient temperature can be adapted to the specific tick species being studied in order to induce this active period, thereby stimulating the desire to eat and accelerating the biological cycle. In 1979, Doube and Kemp (1979) reported that environmental factors, e.g., variation in temperature or relative humidity, influence tick attachment behavior and survival, but do not generally affect feeding duration once ticks are attached to warm-blooded vertebrates. However, since their study, it has been demonstrated that diurnal rhythms and other environmental factors can, in fact, affect engorgement and detachment patterns. For example, mated females of the southern cattle tick Rhipicephalus (Boophilus) microplus engorge most rapidly at night but do not drop-off until the animals begin leaving the cattle sheds, typically in early morning, facilitating the dispersal of the replete female ticks in the host's habitat (Bianchi and Barre 2003). Similarly, nidicolous ticks tend to concentrate their feeding activities during the period when the host is resting or sleeping in the nest or burrow (Olivier 1989). Recently, experiments performed on birds reported the capacity of I. arboricola to extend the duration of attachment when the 
TABLE 1: Summary of the major strengths and weaknesses of techniques used to artificially infect ticks with pathogens. Only key models (ticks and pathogens) and associated references are mentioned here. More specific information can be found in the main text.

\begin{tabular}{|c|c|c|c|c|c|c|}
\hline $\begin{array}{l}\text { Infection } \\
\text { method }\end{array}$ & $\begin{array}{l}\text { Frequency } \\
\text { of use }\end{array}$ & Tick species & $\begin{array}{l}\text { Pathogens } \\
\text { studied }\end{array}$ & Key references & Major strengths & Major weaknesses \\
\hline $\begin{array}{l}\text { Direct feeding } \\
\text { on the host }\end{array}$ & $\begin{array}{l}\text { Many } \\
\text { studies }\end{array}$ & $\begin{array}{l}\text { I. ricinus } \\
\text { D. andersoni } \\
\text { R. appendiculatus } \\
\text { A. variegatum } \\
\text { A. hebraeum } \\
\text { I. ricinus }\end{array}$ & $\begin{array}{l}\text { B. divergens } \\
\text { A. marginale } \\
\text { T. parva } \\
\text { T. mutans } \\
\text { C. ruminantium } \\
\text { B. birtlesii }\end{array}$ & $\begin{array}{l}\text { Joyner et al. , } 1963 \\
\text { Kocan et al. , } 1986 \\
\text { Bailey, } 1960 \\
\text { Young et al. , } 1996 \\
\text { Heyne et al. , } 1987 \\
\text { Reis et al. , 2011a }\end{array}$ & $\begin{array}{l}\text { Physiologically } \\
\text { realistic; Relatively } \\
\text { easy set-up; Ability } \\
\text { to infect a large } \\
\text { quantity of ticks }\end{array}$ & $\begin{array}{l}\text { Expensive; Ethical } \\
\text { considerations; } \\
\text { Inability to quantify } \\
\text { infective dose; } \\
\text { Restricted use for } \\
\text { wild hosts }\end{array}$ \\
\hline Injection & Few studies & $\begin{array}{l}\text { R. appendiculatus } \\
\text { D. andersoni } \\
\text { I. scapularis }\end{array}$ & $\begin{array}{l}\text { T. parva } \\
\text { A. marginale } \\
\text { B. burgdorferi }\end{array}$ & $\begin{array}{l}\text { Jongejan et al. , } 1980 \\
\text { Kocan et al. , } 1996 \\
\text { Kariu et al. , } 2011\end{array}$ & $\begin{array}{l}\text { Ability to quantify } \\
\text { infective dose }\end{array}$ & $\begin{array}{l}\text { Physiologically } \\
\text { unrealistic; High tick } \\
\text { mortality; Live } \\
\text { animals needed } \\
\text { (ethical and logistical } \\
\text { considerations) }\end{array}$ \\
\hline Capillary & $\begin{array}{l}\text { Many } \\
\text { studies }\end{array}$ & $\begin{array}{l}\text { D. andersoni } \\
\text { R. appendiculatus } \\
\text { I. ricinus } \\
\text { A. variegatum } \\
\text { R. sanguineus } \\
\text { D. variabilis } \\
\text { D. variabilis }\end{array}$ & $\begin{array}{l}\text { L. pomona } \\
\text { T. parva } \\
\text { B. burgdorferi } \\
\text { Dugbee virus } \\
\text { E. chaffeensis } \\
\text { A. marginale } \\
\text { R. montana }\end{array}$ & $\begin{array}{l}\text { Burgdorfer, } 1957 \\
\text { Purnel et Joyner, } 1967 \\
\text { Monin et al. , } 1989 \\
\text { Booth et al. , } 1991 \\
\text { Rechav et al. , } 1999 \\
\text { Kocan et al. , } 2005 \\
\text { Macaluso et al. , } 2011\end{array}$ & $\begin{array}{l}\text { Natural infection } \\
\text { route; Ability to } \\
\text { quantify infective } \\
\text { dose }\end{array}$ & $\begin{array}{l}\text { Difficult set-up; Live } \\
\text { animals needed } \\
\text { (ethical and logistical } \\
\text { considerations); } \\
\text { Ingestion of blood } \\
\text { and pathogen not } \\
\text { simultaneous }\end{array}$ \\
\hline $\begin{array}{l}\text { Membrane } \\
\text { (animal skin } \\
\text { or silicone } \\
\text { membrane) }\end{array}$ & $\begin{array}{l}\text { Many } \\
\text { studies }\end{array}$ & $\begin{array}{l}\text { A. variegatum } \\
\text { R. appendiculatus } \\
\text { R. appendiculatus } \\
\text { I. ricinus } \\
\text { I. ricinus }\end{array}$ & $\begin{array}{l}\text { T. mutans } \\
\text { B. ruminantium } \\
\text { T. parva } \\
\text { B. divergens } \\
\text { B. henselae }\end{array}$ & $\begin{array}{l}\text { Voigt et al. , } 1993 \\
\text { Young et al. , } 1996 \\
\text { Wallade et al. , } 1993 \\
\text { Bonnet et al. , } 2007 \\
\text { Cotté et al. , } 2008\end{array}$ & $\begin{array}{l}\text { Natural infection } \\
\text { route; Ingestion of } \\
\text { blood and pathogen } \\
\text { simultaneous; } \\
\text { Ability to quantify } \\
\text { infective dose; No } \\
\text { need for live } \\
\text { animals; Ability to } \\
\text { infect a large } \\
\text { quantity of ticks }\end{array}$ & $\begin{array}{l}\text { Daily change of the } \\
\text { blood (and risk of } \\
\text { contamination); } \\
\text { Membrane } \\
\text { preparation } \\
\text { required; Olfactory } \\
\text { stimuli sometimes } \\
\text { required (for non- } \\
\text { animal membranes) }\end{array}$ \\
\hline
\end{tabular}

host bird did not return to a suitable environment for the tick, with no apparent costs of prolonged attachment (White et al. 2012).

Host-seeking ticks recognize a variety of stimuli from prospective hosts which, in turn, excites their host-finding behavior. Among these, odors are undoubtedly the most important and best-studied stimuli (Waladde and Rice 1982). Carbon dioxide represents one of the most important host-derived odorants and can be used in the laboratory to stimulate tick activity. Radiant heat, such as host's body heat, also acts as a stimulus and acts synergistically with odors (Lees 1948). Other stimuli which ticks may potentially use in host-finding activities have received little attention, especially visual cues and vibrations. Finally, in some instances, tick-derived rather than host-derived stimuli are of critical importance in tick host-seeking behavior. For exam- 
ple, Amblyomma variegatum and A. hebraeum are excited by the $\mathrm{CO}_{2}$ produced by cattle but select tickinfested animals when they detect the aggregationattachment pheromone emitted by attached, feeding ticks (Norval et al. 1989). Based on these studies, stimuli from hosts and pheromones produced by ticks can therefore be used in the laboratory to promote tick feeding.

Some tick species feed only on specific hosts, or on a narrow range of closely related hosts, whereas others may be categorized as opportunistic (Sonenshine 1975). Host specificity results from a process of selective host recognition and the ability of ticks to avoid host rejection (Ribeiro 1987) and can differ between life stages for a given tick species. To a certain extent, host choice is influenced by the height at which ticks seek hosts on the vegetation, but this is by no means the sole determinant of host specificity. Macro- and micro-habitat distribution also influences host selection by favoring encounters between ticks and their hosts. Host selection also requires tick recognition of specific host characteristics, such as host odors, for example. Unfortunately, our understanding of host selection in ticks and the functional basis of host specificity is extremely limited and can be a significant obstacle for tick rearing and study. As some hosts can not being maintained under laboratory conditions, the implementation of specifically-adapted artificial feeding systems may be necessary. For example, as mentioned above, odor from the appropriate host animal may be used to stimulate tick feeding on artificial membranes. Sweat and exfoliated skin collected from horses naturally infested with $A$. cajennense, has been used to stimulate feeding in this tick species (de Moura et al. 1997). In the same way, shredded bovine hair and hair extract (i.e., lipid extracted from freshly shaven hair dissolved in dichloromethane) have been used, respectively, on silicone membranes in order to entice feeding in A. hebraum and I. ricinus, tick species that readily exploit cattle (Krober and Guerin 2007a; Kuhnert et al. 1995).

In conclusion, the general environmental conditions that a tick is exposed to in its natural habitat, including temperature, humidity, diurnal rhythms, activity periods, questing behavior, sensory modal- ities and stimuli, must all be considered carefully when setting up a laboratory system. In many cases, laboratory conditions will need to be adapted to the specific needs of the tick species of interest in order to increase the chances of successful tick feeding and colony establishment.

\section{Systems for maintaining and/or infecting ticks}

\section{Feeding and infection directly on the host}

Despite the constraints associated with host specificity, some tick species can be readily fed in the laboratory on easily handled animals. Indeed, rabbits are classically used to feed ticks in laboratory: immature stages of Rhipicephalus evertsi evertsi (Londt and Van der Bijl 1977), all life stages of I. scapularis, I. pacificus, A. americanum, Dermacentor occidentalis, D. variabilis, Haemaphysalis leporispalustris and R. sanguineus (Troughton and Levin 2007), R. appendiculatus (Bailey 1960), A. variegatum (Voigt et al. 1993), D. andersoni (Howarth and Hokama 1983), A. hebraeum (Heyne et al. 1987), I. ricinus (Bonnet et al. 2007). In these cases, the typical way to engorge ticks is to use feeding bags or capsules glued to clean-shaven skin on the back of the animal (Figure 1). Sometimes, larger animals have been used as blood sources, such as calves for $R$. evertsi evertisi (Londt and Van der Bijl 1977), R. appendicalutus (Musyoki et al. 2004), and D. andersoni (Kocan et al. 1986), or sheep for A. hebraeum (Heyne et al. 1987) and I. ricinus (Bonnet et al. 2007).

The use of natural hosts for tick feeding and methods of direct infection on infectious animals is the method of choice to obtain conditions that are closest to the physiological reality of transmission. However, acquisition, housing, and handling of animal hosts can be complicated, expensive and sometimes even impossible. In fact, in some cases and in particular for wildlife, maintaining the natural host of a specific tick-borne pathogen is impossible in laboratory. There are some examples where wild animals were used as the blood meal source, such as groundhogs for feeding Ixodes cookei (Farkas and Surgeoner, 1991) or tortoises for feeding A. hebraeum (Heyne et al., 1987) but this practice remains exceptional. The most commonly used model of tick infection directly on animals involves pathogens in- 
A

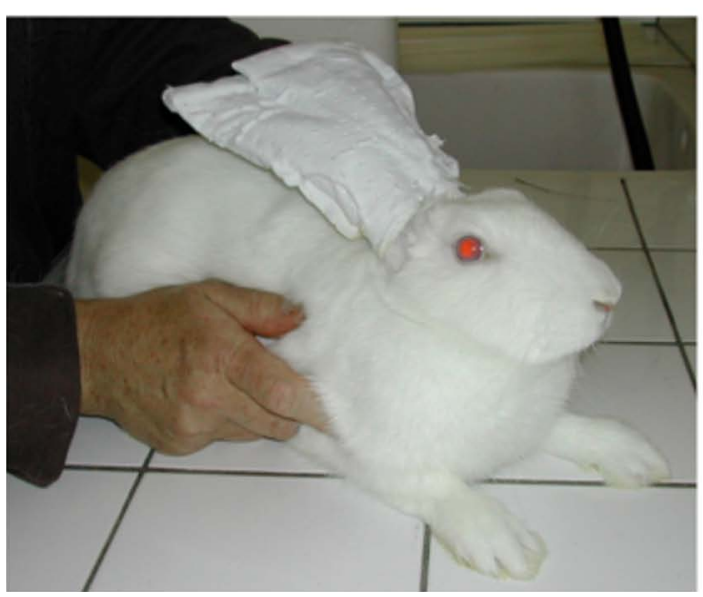

B

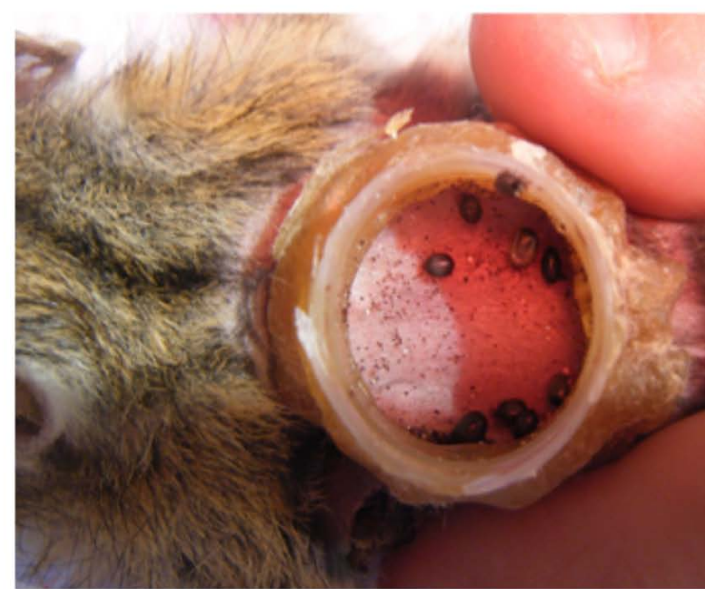

FIGURE 1: Views of Ixodes ricinus feeding in the laboratory on A - rabbit, and B - Siberian chipmunks (Tamias sibiricus barberi). On rabbits, ticks were put in an ear-bag which was placed on shaved ear skin and sealed with tape at the base. Ticks were checked daily until repletion, and were then collected and stored under standardized conditions. For chipmunks, animals were briefly anaesthetized with $3 \%$ Isoflorane and a plastic cap, open at both ends, was glued onto their shaved back with wax. Hungry larvae and nymphs were placed in the cap, which was then sealed with tape. Ticks were allowed to feed until repletion for 5-6 days. At this time, the cap was opened, and the engorged ticks were collected and stored under standardized conditions.

fecting cattle, such as Babesia divergens transmitted by I. ricinus (Donnelly and Peirce 1975; Joyner et al. 1963; Lewis and Young 1980), Anaplasma marginale by D. andersoni (Kocan et al. 1986), Theileria parva by Rhipicephalus appendiculatus (Bailey 1960; Musyoki et al. 2004), or T. mutans and Cowdria ruminantium transmitted by $A$. variegatum (Young et al. 1996). Sheep were used to infect $A$. hebraeum with C. ruminantium (Heyne et al. 1987). Infectious gerbils have been used in order to infect $I$. ricinus with $B$. divergens (Lewis and Young 1980; Mackenstedt et al. 1990). Finally, laboratory mice have also been used for studying Bartonella birtlesii transmission by I. ricinus (Reis et al. 2011a), or Borrelia burgdorferi by I. scapularis (Burkot et al. 2001).

However, with the direct feeding technique, it is impossible to quantify the pathogen dose received by the tick during feeding and thus to standardize the experimental conditions. Even if a venous blood sample is simultaneously analyzed, it may have different pathogen concentrations than the tick's biting site and tick blood meals are too long to monitor temporal changes in pathogen concentrations with any precision. Likewise, for some pathogens, the parasitaemia, bacteraemia or viral peak in the host can be short (1-4 days) and it may be difficult to synchronize it with tick feeding. Finally, for ethical considerations, it is always desirable to limit the use of laboratory animals and thus to find alternative artificial systems.

\section{Infection by injection}

In a few studies, ticks have been infected by direct injection of a suspension containing the pathogen through the cuticle. R. appendiculatus have been successfully infected after inoculation with fresh or cryopreserved blood containing T. parva (Jongejan et al. 1980; Walker et al. 1979), whereas attempts to infect ticks by inoculating cultured stages of T. parva failed (Jongejan et al. 1980). Another study reported that $D$. andersoni exposed percutaneously as nymphs to Anaplasma marginale, transmitted the pathogen to calves as feeding adults, even though no bacterial colonies were detected in gut tissues of the inoculated ticks (maybe because the infective dose was too low or because the bacteria developed in tissues other than gut) (Kocan et al., 1986). In a study aimed at infecting A. americanum, D. variabilis and R. sanguineus with Ehrlichia chaffensis, Rechav et al. (1999) concluded that the inoculation technique by injec- 
tion is not accurate or practical for routine infection of ticks with pathogens because of the low survival rate of inoculated ticks. Recently, a procedure for infecting I. scapularis with B. burgdorferi via a microinjection by the anal aperture was reported and seems more satisfactory in terms of tick survival (Kariu et al. 2011).

When using direct inoculations by injection, the exact assessment of the pathogen dose received by the tick is possible. However, in addition to the high tick mortality previously mentioned (Rechav et al. 1999), this technique does not enable the experimenter to avoid the use of animals for feeding ticks post-infection. Finally, and more importantly, it does not correspond to the normal infection pathway used by the pathogen to infect ticks, which naturally occurs via the mouthpart and the digestive tract during the blood meal. This difference can have important consequences for pathogen development, particularly when the parasite in question undergoes several developmental stages in the tick gut (Chauvin et al. 2009). It has also been demonstrated that bacteria, such as Borrelia burgdorferi, express different molecules depending on the engorgement status of the vector (Hovius et al. 2007). Consequently, the results obtained with direct inoculation systems may be difficult to extrapolate and apply to natural infections.

\section{Infection by capillary feeding}

The use of blood-filled capillary tubes placed over the mouthparts of the tick was first reported in 1938 by Gregson who used this technique to collect saliva from D. andersoni (Gregson 1938). Later, in 1950, Chabaud used it for engorging Haemaphysalis excavatum, $H$. dromedarii and $R$. sanguineus with different nutriment combinations as a means of studying tick nutrition (Chabaud 1950). In Chabaud's study, ticks were pre-fed on the host, removed, and the capillary tube containing various substrates was placed over the tick's mouthparts. Since these initial studies, capillary tubes filled with infectious suspensions have been used for feeding ticks in several biological models: Leptospira pomona / A. maculatum-D. andersoni (Burgdorfer 1957), T. parva / R. appendiculatus (Purnell and Joyner 1967; Walker et al. 1979),
B. burgdorferi / I. ricinus (Kurtenbach et al. 1994; Monin et al. 1989), B. burgdorferi / I. scapularis (Broadwater et al. 2002; Korshus et al. 2004), dugbee virus / A. variegatum (Booth et al. 1991), E. chaffeensis / A. americanum-D. variabilis- $R$. sanguineus (Rechav et al. 1999), A. marginale / D. variabilis (Kocan et al. 2005) or R. montana-R. rhipicephali / D. variabilis (Macaluso et al. 2001). In these studies, capillary feeding was performed either before or after feeding on the animal host, the animal host being necessary in order to feed ticks to repletion.

Tick infection by capillary feeding presents the advantage of using the natural infection route via the mouthparts and the digestive tract. It also permits one to control the amount of fluid ingested by the tick and the titer of the pathogen that enters the tick. However, tick manipulation during the preor post-feeding period on the natural host with a forced removal from the host is delicate in practice. Similarly, only very small amounts of fluid (0.01-0.03 ml) can be ingested by ticks with this technique (Burgdorfer 1957; Rechav et al. 1999) because ticks feed in an unnatural manner. Finally, and most importantly, natural transmission conditions are poorly replicated using this method, as the tick acquires the pathogen in large quantities and without blood. Normally, the pathogen is absorbed by the tick throughout the blood meal period during which time the tick has already begun digestion and the pathogen has started the next step its developmental cycle.

\section{Membrane feeding systems}

The membrane feeding technique consists in feeding ticks through a membrane on blood taken from animals or culture media. It is the most frequently used feeding technique for ticks as demonstrated by two previously published reviews on the subject (Krober and Guerin 2007b; Waladde et al. 1996). In 1956, Pierce and Pierce used air cell membranes from embryonated hen eggs in order to feed R. microplus larvae and nymphs (Pierce and Pierce 1956). Since then, several membranes from different animal origins have been used with variable success to engorge ticks, including pieces of cattle skin for R. microplus (Kemp et al. 1975) and A. variegatum 


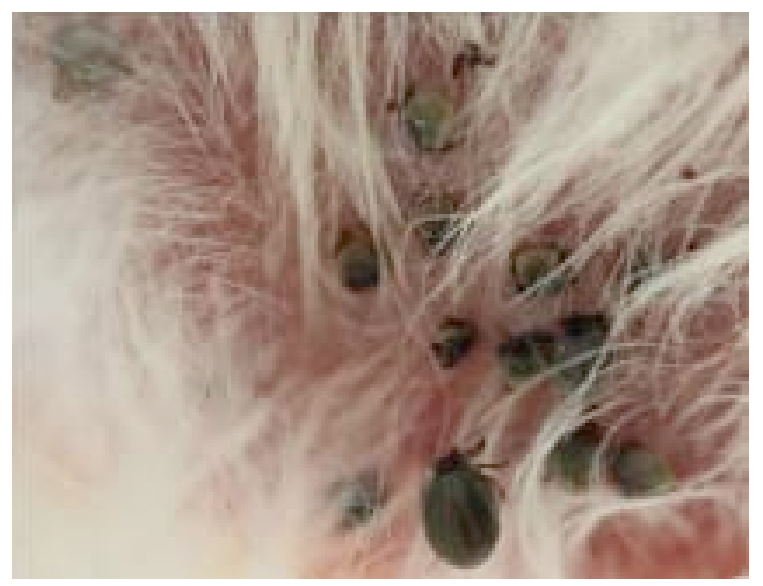

FIGURE 2: View of attached I. ricinus nymphs on a rabbit skin used in the membrane feeding system.

(Voigt et al. 1993; Young et al. 1996), calf mesentery and modified Baudruche membranes for R. microplus (Kemp et al. 1975; Waladde et al. 1979) and R. appendiculatus (Waladde et al. 1991; Young et al. 1996), rabbit skin for A. variegatum (Voigt et al. 1993; Young et al. 1996), D. andersoni (Howarth and Hokama 1983), R. appendiculatus (Musyoki et al. 2004) and I. ricinus (Bonnet et al. 2007) (Figure 2), mouse skin for $D$. andersoni (Howarth and Hokama 1983; Paine et al. 1983) and I. scapularis (Burkot et al. 2001), and gerbil skin for I. ricinus (Bonnet et al. 2007). Membranes of non-animal origin made from silicone have also been used with success, particularly for feeding the different instars of A. hebraeum (Kuhnert et al. 1995), I. ricinus females (Krober and Guerin 2007b), A. cajennense adults (de Moura et al. 1997), and recently $H$. anatolicum anatolicum and $H$. dromedarii (Tajeri and Razmi 2011). However, without the addition of specific stimuli, the use of such membranes has proved ineffective for ticks such as A. variegatum (Voigt et al. 1993). This is related to the fact that one of the greatest difficulties is to encourage the attachment of unfed ticks (see above). It is for this reason that attachment stimuli are always required with silicone membranes, and/or why some authors use these membranes after a prefeeding step on live animals. This was the case, for example, for I. holocyclus where the authors wanted to collect tick-produced toxins to study tick paralysis (Stone et al. 1983). In addition to being logistically difficult, the major disadvantage of arti- ficial membrane systems that employ pre-feeding is the low reattachment success on the membrane (Howarth and Hokama 1983).

However, regardless of the limitations associated with artificial membrane techniques, this method has proved successful in infecting feeding ticks. Howarth and Hokama (1983) were able to obtain infectious adults of $D$. andersoni when the preceding nymphal stages were infected with Anaplasma marginale via an animal skin membrane and after a pre-feeding step on a rabbit. An almost similar protocol was used by Burkot et al. (2001) for successfully infecting I. scapularis ticks with $B$. burgdorferi. Here, ticks were pre-fed on a mouse and the mouse skin was harvested with $I$. scapularis still attached. The skin was then fixed to a glass membrane feeder containing bacterial infected blood (Burkot et al. 2001). In other studies, animal skin membranes have been used with success and without the need of a pre-feeding step on a living animal. A. variegatum was infected with $T$. mutans and Cowdria ruminantium in this way (Voigt et al. 1993; Young et al. 1996), as was R. appendiculatus with the same pathogens and a modified Baudruche membrane (Young et al. 1996). In 1993, Wallade et al. succeeded in transmitting T. parva to susceptible cattle via adult $R$. appendiculatus infected as nymphs through a Baudruche membrane that was made attractive to ticks by the addition of a combination of tactile and olfactory stimuli (Waladde et al. 1993). The same experiment was then reproduced 


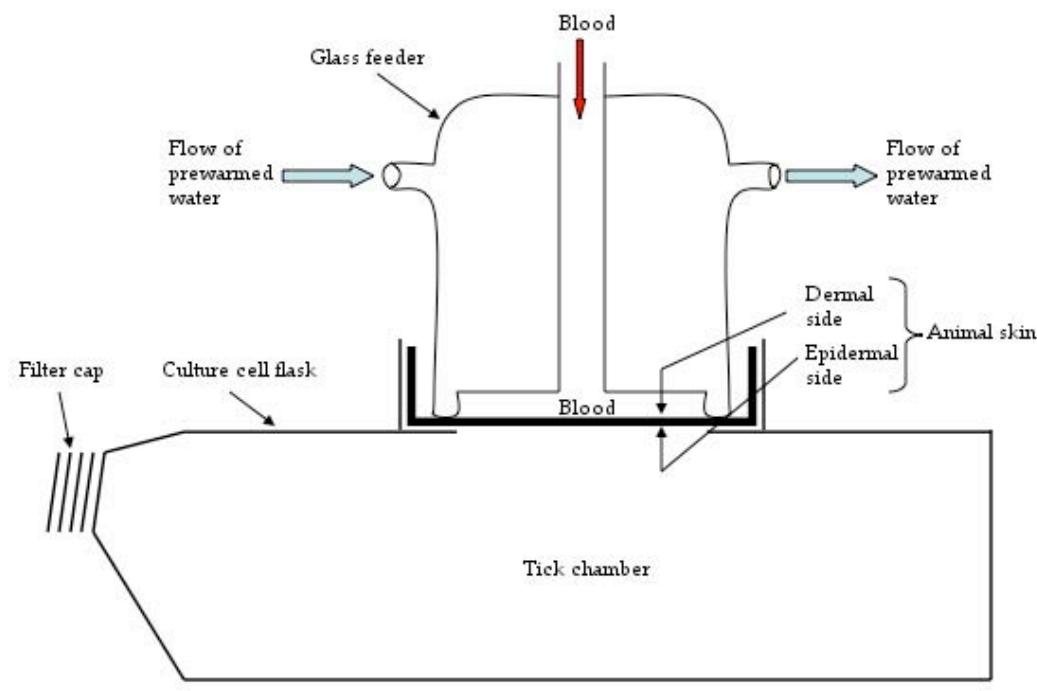

FIGURE 3: Diagram of the membrane feeding apparatus used in the experimental feeding of Ixodes ricinus ticks (adapted from Bonnet et al. 2007).

successfully using rabbit skin membranes (Musyoki et al. 2004). Finally, gerbil (for immature life stages) and rabbit (for adults) skin membranes have been used in order to infect $I$. ricinus with both $B$. divergens and Bartonella henselae without the need for additional stimuli (Bonnet et al. 2007; Cotte et al. 2008).

The membrane feeding apparatus consists of a blood container with a membrane placed either on the top (Bonnet et al. 2007; Burkot et al. 2001; Musyoki et al. 2004; Voigt et al. 1993; Young et al. 1996) or the bottom (Howarth and Hokama 1983; Kuhnert et al. 1995; Paine et al. 1983; Waladde et al. 1991) of the tick containment unit. Placing the blood above the membrane favors a continuous gravitational pressure on the membrane and is essential for infection with intraerythrocytic pathogens because of the rapid sedimentation of the red blood cells. Several tick-feeding devices with different blood containment units have been explored and tested, including plastic cylinders (Young et al. 1996), plate wells (Howarth and Hokama 1983; Krober and Guerin 2007a), honey jars (Kuhnert et al. 1995) or glass feeders (Bonnet et al. 2007) as represented on figure 3 .

In order to mimic the host environment more closely, a temperature $\left(35-39^{\circ} \mathrm{C}\right)$ adapted to the tick species of interest should be applied either to the incubator, where the whole apparatus is placed, or just to the blood. As already mentioned, olfactory stimuli for attachment and feeding are sometimes required and are indispensable in the case of membranes from non-animal origins. The required stimuli could differ depending on the species and genera of ixodid ticks under study. A carbon dioxide atmosphere has been used as stimulant for tick attachment, between 5 and $10 \% \mathrm{CO}_{2}$ for $A$. variegatum for example (Voigt et al. 1993; Young et al. 1996). Host hair, tick feces, animal fur extracts and synthetic aggregation-attachment pheromone mixtures have all been used for stimulating the attachment of A. hebraeum (Kuhnert et al. 1995). For stimulating $R$. appendiculatus feeding, Young et al. (1996) also used cattle/tick washes and tick feces. However, de Moura et al. (1997) demonstrated that for A. cajennense silicone membranes treated with blood vestiges was more efficient than other tested phagostimulants. Finally, adenosine triphosphate (ATP) and reduced glutathione have also been used as phagostimulants (Kuhnert et al. 1995; Paine et al. 1983). Finally, membrane thickness must be adapted to the size of the tick's mouthparts which can be short or long depending on the genera and the tick life stage. 
Membrane feeding techniques mimic the natural conditions of tick infection more closely than other methods because pathogens are mixed in blood and are absorbed throughout the blood meal via the digestive tract. In most cases, using animal skin membranes has the important advantage that no tick pre-feeding is required for attachment and engorgement on the membrane, and no attachment stimuli are required. It is, on the other hand, necessary to sacrifice laboratory animals in order to obtain the skins and to carefully prepare them (Bonnet et al. 2007; Musyoki et al. 2004) to avoid any biodegradation and blood contamination. The final engorgement weight of membrane-fed ticks also tends to be lower (or equal) than that of animal fed ticks (Musyoki et al. 2004; Voigt et al. 1993; Young et al. 1996), even if molting and egg-laying success are generally comparable. Membrane feeding permits a direct assessment of pathogen concentration in the blood sample ingested by the ticks. Repeated assays with large tick numbers are also possible with this system. Finally, membrane-feeding techniques can allow one to evaluate the effects of drugs or transmission-blocking blood components, as well as helping to elucidate attachment stimuli, feeding stimuli and nutritional requirements of ticks. Feeding immature stages presents less difficulty than for adults because of their shorter feeding times. Indeed, the principal difficulty with this technique resides in maintaining a continuous bloodmeal without contamination by bacteria or fungi during the slow blood-feeding process and the required daily changes of the blood. In addition, the mouthparts and oral secretions of the ticks can also contaminate the blood in the feeding device because of the absence of host defense mechanisms. However, the addition of antibiotic and antifungal products to the circulating blood can prevent this problem. To favor feeding, anticoagulants should also be used and it was reported that heparinized blood was found to be the most suitable for tick feeding (Voigt et al. 1993; Waladde et al. 1993; Young et al. 1996). Consequently, within the framework of experimental pathogen transmission, it is necessary to test pathogen viability under the tick feeding conditions beforehand.

\section{CONCLUSIONS}

Ticks possess many unusual features that contribute to their remarkable success and vector potential. One of the most outstanding is their longevity and their reproductive potential (i.e., ability to produce large numbers of eggs), which makes them substantial pathogen reservoirs in the field. Another is the fact that they are pool feeders (i.e., sucking all the fluids and potential pathogens that are exuded into the wound generated by the bite). During feeding, they absorb a very large quantity of blood and over a relatively long period of time, thereby increasing the chance of ingesting a pathogen. It is this last parameter that makes them particularly difficult to study in the laboratory because these natural conditions are complicated to replicate. Nevertheless, there is no doubt that effective in vitro feeding systems for Ixodid ticks of medical and veterinary importance have major benefits. Even if feeding ticks on live experimental animals seems the simplest, it is not always practicable according to the biological model and may be considered as ethically debatable. Various methods have therefore been elaborated to feed and infect ticks artificially, among which the membrane feeding technique mimics reality more closely than the other techniques. However, each technique has strengths and weaknesses and the chosen method will depend on the question addressed. In all cases, infecting ticks under controlled conditions enables one to test a great spectrum of biological questions, including the ability to study the development of pathogens inside their vectors, to uncover transmission pathways, and to evaluate the influence of biologically active substances exchanged between host and vector. For now, these techniques all tend to have long and difficult set-up periods, giving sometimes unpredictable results. Efforts to standardize and simplify laboratory protocols, which would greatly improve our ability to exploit these methods, should now be the aim of future work.

\section{ACKNOWLEDGEMENTS}

Thanks are due to the "Tiques et Maladies à Tiques" working group (REID - Réseau Ecologie des In- 
teractions Durables) for stimulating discussions. Part of the presented work was funded by EU grant FP7-261504 EDENext and is catalogued by the EDENext Steering Committee as EDENext000 (http://www.edenext.eu). The contents of this publication are the sole responsibility of the author and do not necessarily reflect the views of the European Commission. Acknowledgements are also due to B. Allouche from the DSI of ENVA for use of photographs and to Dr K. McCoy and E. Fillol for their critical reading of the manuscript.

\section{REFERENCES}

Bailey K.P. 1960 - Note on the rearing of Rhipicephalus appendiculatus and their infection with Theileria parva for experimental transmission. - Bull. Epizoot. Dis. Afr., 8: 33-43.

Bianchi M.W., Barre N. 2003 - Factors affecting the detachment rhythm of engorged Boophilus microplus female ticks (Acari: Ixodidae) from Charolais steers in New Caledonia - Veterinary parasitology, 112: 32536. doi:10.1016/S0304-4017(02)00271-6

Bonnet S., Jouglin M., Malandrin L., Becker C., Agoulon A., L'Hostis M., Chauvin A. 2007 - Transstadial and transovarial persistence of Babesia divergens DNA in Ixodes ricinus ticks fed on infected blood in a new skin-feeding technique - Parasitology, 134: 197-207.

Booth T.F., Steele G.M., Marriott A.C., Nuttall P.A. 1991 — Dissemination, replication, and trans-stadial persistence of Dugbe virus (Nairovirus, Bunyaviridae) in the tick vector Amblyomma variegatum - The American journal of tropical medicine and hygiene, 45: 146-57.

Broadwater A.H., Sonenshine D.E., Hynes W.L., Ceraul S., De S.A. 2002 - Glass capillary tube feeding: a method for infecting nymphal Ixodes scapularis (Acari: Ixodidae) with the lyme disease spirochete Borrelia burgdorferi - J. Med. Entomol., 39: 285-92. doi:10.1603/0022-2585-39.2.285

Burgdorfer W. 1957 - Artificial feeding of ixodid ticks for studies on the transmission of disease agents The Journal of infectious diseases, 100: 212-4. doi:10.1093/infdis/100.3.212

Burkot T.R., Happ C.M., Dolan M.C., Maupin G.O. 2001 - Infection of Ixodes scapularis (Acari: Ixodidae) with Borrelia burgdorferi using a new artificial feeding technique - J. Med. Entomol., 38: 167-71. doi:10.1603/0022-2585-38.2.167

Chabaud A.G. 1950 - Sur la nutrition artificielle des tiques - Ann. Parasitol. Hum. Comp., 25: 142-147.
Chauvin A., Moreau E., Bonnet S., Plantard O., Malandrin L. 2009 - Babesia and its hosts: adaptation to long-lasting interactions as a way to achieve efficient transmission - Vet. Res., 40: 37. doi:10.1051/vetres/2009020

Cotte V., Bonnet S., Le Rhun D., Le Naour E., Chauvin A., Boulouis H.J., Lecuelle B., Lilin T., VayssierTaussat M. 2008 - Transmission of Bartonella henselae by Ixodes ricinus - Emerg. Infect. Dis., 14: 107480. doi:10.3201/eid1407.071110

Crippa M., Rais O., Gern L. 2002 - Investigations on the mode and dynamics of transmission and infectivity of Borrelia burgdorferi sensu stricto and Borrelia afzelii in Ixodes ricinus ticks - Vector Borne Zoonotic Dis, 2: 3-9. doi:10.1089/153036602760260724

de Moura S.T., da Fonseca A.H., Fernandes C.G., Butler J.F. 1997 - Artificial feeding of Amblyomma cajennense (Fabricius, 1787) (Acari:Ixodidae) through silicone membrane. - Mem Inst Oswaldo Cruz, 92: 5458. doi:10.1590/S0074-02761997000400019

de Souza M.S., Smith A.L., Beck D.S., Kim L.J., Hansen G.M., Jr., Barthold S.W. 1993 - Variant responses of mice to Borrelia burgdorferi depending on the site of intradermal inoculation - Infection and immunity, 61: 4493-7.

Donnelly J., Peirce M.A. 1975 - Experiments on the transmission of Babesia divergens to cattle by the tick Ixodes ricinus - Int. J. Parasitol., 5: 363-7. doi:10.1016/0020-7519(75)90085-5

Doube B.M., Kemp D.H. 1979 - The influence of temperature, relative humidity and host factors on the attachment and survival of Boophilus microplus (Canestrini) larvae to skin slices - Int. J. Parasitol., 9: 449-54. doi:10.1016/0020-7519(79)90048-1

Farkas M., Surgeoner G. 1991 - Developmental times and fecundity of Ixodes cookei packard (Acari: Ixodidae) under laboratory conditions - The Canadian Entomologist, 123: 1-11. doi:10.4039/Ent1231009-5

Gern L., Schaible U.E., Simon M.M. 1993 - Mode of inoculation of the Lyme disease agent Borrelia burgdorferi influences infection and immune responses in inbred strains of mice - The Journal of infectious diseases, 167: 971-5. doi:10.1093/infdis/167.4.971

Gregson J.D. 1938 - Notes on some phenomenal feeding of ticks - Proc. ent. Soc. Br. Columb., 34: 8.

Heyne H., Elliott E.G., Bezuidenhout J.D. 1987 - Rearing and infection techniques for Amblyomma species to be used in heartwater transmission experiments The Onderstepoort journal of veterinary research, 54: 461-71.

Hovius J.W., van Dam A.P., Fikrig E. 2007 — Tick-hostpathogen interactions in Lyme borreliosis - Trends Parasitol, 23: 434-8. doi:10.1016/j.pt.2007.07.001 
Howarth J.A., Hokama Y. 1983 - Artificial feeding of adult and nymphal Dermacentor andersoni (Acari: Ixodidae) during studies on bovine anaplasmosis - J. Med. Entomol., 20: 248-56.

Jongejan F., Perie N.M., Franssen F.F., Uilenberg G. 1980 - Artificial infection of Rhipicephalus appendiculatus with Theileria parva by percutaneous injection Res. Vet. Sci., 29: 320-4.

Joyner L.P., Davies S.F., Kendall S.B. 1963 - The experimental transmission of Babesia divergens by Ixodes ricinus - Exp. Parasitol., 14: 367-73. doi:10.1016/00144894(63)90044-4

Kariu T., Coleman A.S., Anderson J.F., Pal U. 2011 Methods for rapid transfer and localization of lyme disease pathogens within the tick gut - Journal of visualized experiments : JoVE.

Kemp D.H., Koudstaal D., Roberts J.A., Kerr J.D. 1975 Feeding of Boophilus microplus larvae on a partially defined medium through thin slices of cattle skin - Parasitology, 70: 243-54.

Kocan K.M., Wickwire K.B., Hair J.A., Ewing S.A., Barron S.J. 1986 - Percutaneous infection of nymphal Dermacentor andersoni with Anaplasma marginale - Am. J. Vet. Res., 47: 1662-4.

Kocan K.M., Yoshioka J., Sonenshine D.E., de la Fuente J., Ceraul S.M., Blouin E.F., Almazan C. 2005 - Capillary tube feeding system for studying tick-pathogen interactions of Dermacentor variabilis (Acari: Ixodidae) and Anaplasma marginale (Rickettsiales: Anaplasmataceae) - J. Med. Entomol., 42: 864-74. doi:10.1603/00222585(2005)042[0864:CTFSFS]2.0.CO;2

Korshus J.B., Munderloh U.G., Bey R.F., Kurtti T.J. 2004 - Experimental infection of dogs with Borrelia burgdorferi sensu stricto using Ixodes scapularis ticks artificially infected by capillary feeding - Medical microbiology and immunology, 193: 27-34. doi:10.1007/s00430-003-0178-x

Krober T., Guerin P.M. 2007a - An in vitro feeding assay to test acaricides for control of hard ticks - Pest management science, 63: 17-22. doi:10.1002/ps.1293

Krober T., Guerin P.M. 2007b - In vitro feeding assays for hard ticks - Trends Parasitol, 23: 445-9. doi:10.1016/j.pt.2007.07.010

Kuhnert F., Diehl P.A., Guerin P.M. 1995 - The lifecycle of the bont tick Amblyomma hebraeum in vitro — Int. J. Parasitol., 25: 887-96. doi:10.1016/00207519(95)00009-Q

Kurtenbach K., Dizij A., Seitz H.M., Margos G., Moter S.E., Kramer M.D., Wallich R., Schaible U.E., Simon M.M. 1994 - Differential immune responses to Borrelia burgdorferi in European wild rodent species influence spirochete transmission to Ixodes ricinus L.
(Acari: Ixodidae) — Infection and immunity, 62: 534452.

Lees A.D. 1948 - The sensory physiology of the sheep tick, Ixodes ricinus (L.). - J. Exp. Biol. , 25: 145-207.

Lewis D., Young E.R. 1980 - The transmission of a human strain of Babesia divergens by Ixodes ricinus ticks — J. Parasitol., 66: 359-60. doi:10.2307/3280841

Londt J.G., Van der Bijl E.B. 1977 - The life cycle of the two-host tick Rhipicephalus evertsi evertsi Neumann, 1897, under laboratory conditions (Acarina: Ixodidae). - The Onderstepoort journal of veterinary research, 44: 21-28.

Macaluso K.R., Sonenshine D.E., Ceraul S.M., Azad A.F. 2001 - Infection and transovarial transmission of Rickettsiae in Dermacentor variabilis ticks acquired by artificial feeding. - Vector Borne and Zoonotic Diseases, 1: 45-53. doi:10.1089/153036601750137660

Mackenstedt U., Gauer M., Mehlhorn H., Schein E., Hauschild S. 1990 - Sexual cycle of Babesia divergens confirmed by DNA measurements - Parasitol. Res., 76: 199-206. doi:10.1007/BF00930815

Massung R.F., Priestley R.A., Levin M.L. 2004 — Transmission route efficacy and kinetics of Anaplasma phagocytophilum infection in white-footed mouse, Peromyscus leucopus - Vector Borne Zoonotic Dis, 4: 310-8. doi:10.1089/vbz.2004.4.310

Monin R., Gern L., Aeschlimann A. 1989 - A study of the different modes of transmission of Borrelia burgdorferi by Ixodes ricinus. — Zbl. Bakt. Suppl., 18: 14-20.

Motameni A.R., Bates T.C., Juncadella I.J., Petty C., Hedrick M.N., Anguita J. 2005 - Distinct bacterial dissemination and disease outcome in mice subcutaneously infected with Borrelia burgdorferi in the midline of the back and the footpad - FEMS immunology and medical microbiology, 45: 279-84. doi:10.1016/j.femsim.2005.05.001

Musyoki J.M., Osir E.O., Kiara H.K., Kokwaro E.D. 2004 - Comparative studies on the infectivity of Theileria parva in ticks fed in vitro and those fed on cattle - Exp. Appl. Acarol., 32: 51-67. doi:10.1023/B:APPA.0000018159.47700.e4

Norval R.A., Andrew H.R., Yunker C.E. 1989 Pheromone-mediation of host-selection in bont ticks (Amblyomma hebraeum koch) - Science, 243: 364-5. doi:10.1126/science. 2911745

Nuttall P.A. 1999 - Pathogen-tick-host interactions: Borrelia burgdorferi and TBE virus - Zentralblatt fur Bakteriologie : international journal of medical microbiology, 289: 492-505.

Olivier J.H. 1989 - Biology and systematics of ticks (Acari:Ixodida). - Ann. Rev. Ecol Syst., 20: 397-430. doi:10.1146/annurev.es.20.110189.002145 
Paine S.H., Kemp D.H., Allen J.R. 1983 — In vitro feeding of Dermacentor andersoni (Stiles): effects of histamine and other mediators - Parasitology, 86 (Pt 3): 419-28.

Pierce A.E., Pierce M.H. 1956 - A note on the cultivation of Boophilus microplus (Canestrini, 1887) (Ixodidae: Acarina) on the embryonated hen egg. - Aust. Vet. J., 32: 144-146. doi:10.1111/j.1751-0813.1956.tb05639.x

Piesman J. 1993 - Standard system for infecting ticks (Acari: Ixodidae) with the Lyme disease spirochete, Borrelia burgdorferi — J. Med. Entomol., 30: 199-203.

Purnell R.E., Joyner L.P. 1967 - Artificial feeding technique for Rhipicephalus appendiculatus and the transmisison of Theileria parva from the salivary secretion. Nature, 216: 484-485. doi:10.1038/216484a0

Rechav Y., Zyzak M., Fielden L.J., Childs J.E. 1999 Comparison of methods for introducing and producing artificial infection of ixodid ticks (Acari: Ixodidae) with Ehrlichia chaffeensis - J. Med. Entomol., 36: 414-9.

Reis C., Cote M., Le Rhun D., Lecuelle B., Levin M.L., Vayssier-Taussat M., Bonnet S.I. 2011a - Vector competence of the tick Ixodes ricinus for transmission of Bartonella birtlesii — PLoS Negl Trop Dis, 5: e1186. doi:10.1371/journal.pntd.0001186

Ribeiro J.M. 1987 - Role of saliva in blood-feeding by arthropods - Annual review of entomology, 32: 46378. doi:10.1146/annurev.en.32.010187.002335

Sonenshine D.E. 1975 - Influence of host-parasite interactions on the population dynamics of ticks. - Misc. Publ. Entomol. Soc. Amer., 9: 243-249.

Sonenshine D.E. 1991 - Biology of ticks - New York, USA: Oxford University Press, Inc.

Stone B.F., Commins M.A., Kemp D.H. 1983 - Artificial feeding of the Australian paralysis tick, Ixodes holocyclus and collection of paralysing toxin - Int. J. Parasitol., 13: 447-54. doi:10.1016/S0020-7519(83)80007-1

Tajeri S., Razmi G.R. 2011 - Hyalomma anatolicum anatolicum and Hyalomma dromedarii (Acari: Ixodidae) imbibe bovine blood in vitro by utilizing an artificial feeding system - Veterinary parasitology, 180: 332-5. doi:10.1016/j.vetpar.2011.03.014

Troughton D.R., Levin M.L. 2007 - Life cycles of seven ixodid tick species (Acari: Ixodidae) under standardized laboratory conditions - J. Med. Entomol., 44: 732-40. doi:10.1603/00222585(2007)44[732:LCOSIT]2.0.CO;2
Voigt W.P., Young A.S., Mwaura S.N., Nyaga S.G., Njihia G.M., Mwakima F.N., Morzaria S.P. 1993 - In vitro feeding of instars of the ixodid tick Amblyomma variegatum on skin membranes and its application to the transmission of Theileria mutans and Cowdria ruminatium - Parasitology, 107 ( Pt 3): 257-63.

Waladde S.M., Kemp D.H., Rice M.J. 1979 - Feeding electrograms and fluid uptake measurements of cattle tick Boophilus microplus attached on aertificial membranes. - Int. J. Parasitol., 9: 89-95. doi:10.1016/00207519(79)90096-1

Waladde S.M., Ochieng S.A., Gichuhi P.M. 1991 Artificial-membrane feeding of the ixodid tick, Rhipicephalus appendiculatus, to repletion - Exp. Appl. Acarol., 11: 297-306. doi:10.1007/BF01202876

Waladde S.M., Rice M.J. 1982 - The sensory basis of tick feeding behavior. - In: Obenchain F.D.a.G., R., (Ed). The physiology of ticks. Oxford: Pergamon Press. p. 71-118.

Waladde S.M., Young A.S., Morzaria S.P. 1996 - Artificial feeding of Ixodid ticks - Parasitology Today, 12: 272-278. doi:10.1016/0169-4758(96)10027-2

Waladde S.M., Young A.S., Ochieng S.A., Mwaura S.N., Mwakima F.N. 1993 - Transmission of Theileria parva to cattle by Rhipicephalus appendiculatus adults fed as nymphae in vitro on infected blood through an artificial membrane - Parasitology, 107 (Pt 3): 249-56.

Walker A.R., Brown C.G., Bell L.J., McKellar S.B. 1979 Artificial infection of the tick Rhipicephalus appendiculatus with Theileria parva - Res. Vet. Sci., 26: 264-5.

White J., Heylen D.J., Matthysen E. 2012 - Adaptive timing of detachment in a tick parasitizing hole-nesting birds - Parasitology, 139: 264-70.

Young A.S., Waladde S.M., Morzaria S.P. 1996 - Artificial feeding systems for ixodid ticks as a tool for study of pathogen transmission - Ann N Y Acad Sci, 791: 211-8. doi:10.1111/j.1749-6632.1996.tb53527.x

\section{COPYRIGHT}

$($ (c) EY-No-ND Bonnet S. and Liu X.Y. Acarologia is under free license. This open-access article is distributed under the terms of the Creative Commons-BY-NC-ND which permits unrestricted non-commercial use, distribution, and reproduction in any medium, provided the original author and source are credited. 